\title{
WOUND CLOSURE IN TREES AFFECTED BY PACLOBUTRAZOL
}

\author{
By Shuju Bai ${ }^{1}$, William R. Chaney ${ }^{2}$, and Yadong $\mathrm{Qi}^{3}$
}

\begin{abstract}
Experiments were conducted to investigate the effects of paclobutrazol on closure of wounds made through the bark or resulting from pruning branches in nine species of trees. The species studied were American sycamore (Platanus occidentalis L.), black walnut (Juglans nigra L.), European black alder (Alnus glutinosa L.), red oak (Quercus rubra L.), sweetgum (Liquidambar styraciflua L.), white ash (Fraxinus americana L.), white oak (2. alba L.), white pine (Pinus strobus L.), and yellow poplar (Liriodendron tulipifera L.). Paclobutrazol was applied using either the soil drench or soil injection method. Circular wounds ( $2 \mathrm{~cm}$ [0.8 in.] diameter) were made in the bark on the main stem, and branches were pruned from treated and untreated trees at the time of paclobutrazol application in the spring. The rate of wound closure was determined one, two, and three growing seasons after treatment. The rate of bark wound closure was reduced in paclobutrazol-treated black walnut, European black alder, red oak, sweetgum, and white oak. There was no difference in the rate of closure of wounds in the bark of treated and untreated American sycamore, white ash, white pine, or yellow poplar. The rate of pruning wound closure was reduced in black walnut, European black alder, red oak, sweetgum, and white oak, but was not influenced by paclobutrazol treatment in white ash, white pine, or yellow poplar. The inhibitory effect of paclobutrazol on closure of both bark and pruning wounds in some species persisted at least 3 years.
\end{abstract}

Key Words. Bark wound; growth retardant; paclobutrazol; pruning wound; tree growth regulator; wound closure.

The growth regulator paclobutrazol (PBZ), used by arborists to reduce shoot growth, has been shown to have additional positive effects on trees and shrubs, including improved resistance to drought stress, darker green leaves, protection against some fungal and bacterial pathogens, and enhanced development of fibrous roots (Chaney et al. 1996; Fletcher et al. 2000; Rademacher 2000; Chaney 2003). Cambial growth as well as shoot growth has also been shown to be reduced in some tree species (Bai et al. 2004).

Wounds are considered potentially detrimental to trees because they expose tissues to invasion by insects and to disease-causing and decay organisms. Infection of the phloem or xylem by primary and secondary invaders may result in wood discoloration and decay (Shigo 1989). Yet branch pruning is a sound and often essential arboricultural practice. When branch removal is necessary, rapid closure of pruning wounds is considered desirable for both aesthetic and protective reasons because few pathogens or parasitic microorganisms can penetrate this barrier (Shigo 1984).
Trees have an inherent capacity to seal wounds resulting from injury or pruning. Undifferentiated callus tissue originates from cells of the cambium around the outer periphery of the wound, gradually overgrowing the surface of the wound. Greater development of callus from the side of wounds than at the top and bottom sometimes results in an elliptical shape as the wound sealing process progresses (Neely 1970; Biggs 1992). New cambium develops adjacent to and usually in continuity with the existing undisturbed cambium (Zimmerman and Brown 1971; Biggs 1992; Blanchette 1992). This growth extending over a wound results in the strongest barrier in the wound-sealing process and is referred to as Wall 4 of the compartmentalization of decay in trees (CODIT) model (Shigo 1989).

Our study was designed to investigate the effect of PBZ on the rate of closure of wounds in the bark and wounds made when branches were pruned. The research was conducted in response to concerns that, because PBZ reduces cambial growth as well as shoot growth, it might also reduce the rate of wound closure, thus prolonging the exposure of trees to decay and disease organisms.

\section{MATERIALS AND METHODS}

Experimental trees were located at Martell Experimental Forest Farm near the Purdue University campus in Tippecanoe County, Indiana, U.S. Two experiments were designed using combinations of nine tree species.

Experiment I involved eight species ranging from 4 to 8 cm (1.6 to 3.2 in.) basal diameter and treated in April 1996 using the soil injection method: black walnut (Juglans nigra L.), European black alder (Alnus glutinosa L.), red oak (Quercus rubra L.), sweetgum (Liquidambar styraciflua L.), white ash (Fraxinus americana L.), white oak (Quercus alba L.), white pine (Pinus strobus L.), and yellow poplar (Liriodendron tulipifera L.).

Experiment II investigated two species, American sycamore (Platanus occidentalis L.) (18 to $22 \mathrm{~cm}$ [7.1 to $8.7 \mathrm{in.]}$ average basal diameter) and yellow poplar (Liriodendron tulipifera L.) (14 to $16 \mathrm{~cm}$ [5.5 to 6.3 in.] average basal diameter), treated in April 1998 using the soil drench method.

Twelve (Experiment I) or eighteen (Experiment II) plantationgrown trees $(2 \times 2 \mathrm{~m}[6.6 \times 6.6 \mathrm{ft}]$ spacing $)$ of each species used in the respective experiments were selected based on their similar size and condition. Adjacent trees were not selected for the studies to avoid root interaction and the 
unintended exposure to PBZ treatment. Half of the trees for each species used in Experiment I were randomly assigned to each of two different treatment groups. PBZ formulated as Profile 2SC (SePRO Corporation, Carmel, IN) or water as a control was applied. American sycamore and yellow poplar (Experiment II) were randomly divided into three groups. PBZ was applied as a soil drench at two dose rates to two of the three groups. Trees in the control group were treated with water.

The dose rate for the eight species treated in Experiment I was $9.6 \mathrm{~g}(0.34 \mathrm{oz})$ PBZ per tree in $500 \mathrm{~mL}(17 \mathrm{oz})$ water. In Experiment II, American sycamore and yellow poplar were treated with PBZ using two high dose rates: $15.4 \mathrm{~g} \mathrm{(0.5} \mathrm{oz)} \mathrm{in}$ $800 \mathrm{~mL}(27 \mathrm{oz}$ ) water and $30.7 \mathrm{~g}(1 \mathrm{oz})$ in 1,600 mL (54 oz) water. In the soil injection method (Experiment I), two 250 $\mathrm{mL}(8.5 \mathrm{oz}$ ) aliquots of the ready-to-use (RTU) solution were injected at a pressure of $10.5 \mathrm{~kg} / \mathrm{cm}^{2}(150 \mathrm{psi})$ approximately $15 \mathrm{~cm}$ (6 in.) below the soil surface on opposite sides of each tree within 5 to $20 \mathrm{~cm}$ (1.9 to $7.9 \mathrm{in}$.) of the trunk base. For the soil drench application (Experiment II), the RTU PBZ solution was poured into a shallow moat around the base of each tree. Water was applied using the same method to control trees.

At the time of PBZ treatment, two circular wounds, each $2 \mathrm{~cm}$ (0.8 in) in diameter, were cut through the bark and cambium with a cork borer to expose wood (xylem) immediately below the cambium on the north and south sides of the central stem of each tree $30 \mathrm{~cm}$ (12 in.) above ground level. Vertical and horizontal dimensions of these wounds were measured in millimeters with a caliper at the end of each subsequent growing season for 3 years to determine the rate of wound closure resulting from growth of callus tissue. The exposed area (A) of the bark wound was initially calculated as a circle using the formula $A=\pi r^{2}$, where $r$ is the radius of the circle, and as an ellipse after wound closure was initiated using the formula $A=\pi a b / 4$, where $a$ is the vertical dimension and $b$ is the horizontal dimension.

At the time of treatment with PBZ, two lateral branches chosen at random also were removed from each tree in Experiment I using a pruning saw and taking care to make proper cuts. The width and length of the resulting pruning wounds were measured at the time of pruning and at the end of each subsequent growing season for 3 years to determine the rate of growth of callus tissue surrounding the pruning wounds. The area of each pruning wound was calculated as described above for bark wounds. Closure rate was expressed as a percentage of the initial wound surface area.

One half of the trees of each species in Experiment I were harvested during February and March (3 years after treatment) by cutting them at the ground line with a chain saw. The trunk sections containing the bark wounds were dissected with a band saw to reveal cross and longitudinal sections through the wounds. These sections were examined qualitatively for the extent of discoloration and visual signs of decay related to the wounds.

Both experiments were a completely randomized design, and data from each experiment were analyzed separately using analysis of variance. Differences between means were determined using Tukey's Studentized Range (HSD) test, $P \leq 0.05$.

\section{RESULTS}

\section{Closure of Bark Wounds}

Closure of bark wounds (Experiment I) in white oak, red oak, sweetgum, and black walnut was significantly less at the end of the first growing season in trees treated with PBZ. The same pattern continued for the second season (Figure 1 and Table 1). At the end of the third growing season following treatment, wound closure of treated white oak, sweetgum, and black walnut was still less than in control trees. PBZ treated red oak trees three years after treatment had almost fully closed the wounds so that statistical differences between treated and control trees did not exist. The control sweetgum totally closed the bark wound in the second year after treatment. Control black walnut did not
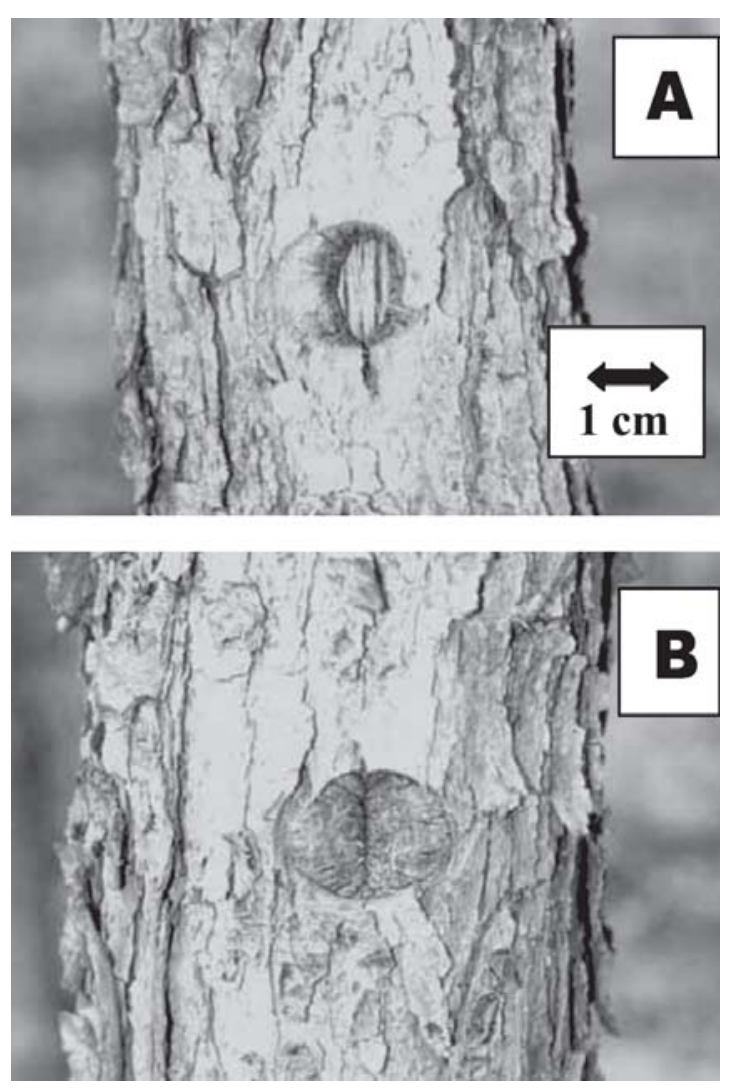

Figure 1. Two-year-old bark wounds on stems of white oak (Quercus alba) in Indiana, treated (A) and untreated (B) with paclobutrazol. 
Table 1. Area $\left(\mathrm{mm}^{2}\right)$ of 1-, 2- and 3-year-old bark wounds in eight tree species treated and untreated with $9.6 \mathrm{~g}$ PBZ by soil injection.

\begin{tabular}{|c|c|c|c|c|c|}
\hline Species & Treatment & Initial area & 1 year later & 2 years later & 3 years later \\
\hline White oak & Treated & 314.2 & $142.5 a^{*}$ & $77.5 \mathrm{a}$ & $9.8 \mathrm{a}$ \\
\hline (Quercus alba) & Control & 314.2 & $43.3 \mathrm{~b}$ & $3.9 \mathrm{~b}$ & $0.0 \mathrm{~b}$ \\
\hline Red oak & Treated & 314.2 & $136.3 \mathrm{a}$ & $39.0 \mathrm{a}$ & $4.7 \mathrm{a}$ \\
\hline (Q. rubra) & Control & 314.2 & $78.2 \mathrm{~b}$ & $3.1 \mathrm{~b}$ & $0.0 \mathrm{a}$ \\
\hline Sweetgum & Treated & 314.2 & $84.9 \mathrm{a}$ & $65.5 \mathrm{a}$ & $58.3 \mathrm{a}$ \\
\hline (Liquidambar styraciflua) & Control & 314.2 & $24.1 \mathrm{~b}$ & $0.0 \mathrm{~b}$ & $0.0 \mathrm{~b}$ \\
\hline Black walnut & Treated & 314.2 & $119.0 \mathrm{a}$ & $81.0 \mathrm{a}$ & $57.5 \mathrm{a}$ \\
\hline (Juglans nigra) & Control & 314.2 & $57.2 \mathrm{~b}$ & $23.6 \mathrm{~b}$ & $7.4 \mathrm{~b}$ \\
\hline European black alder & Treated & 314.2 & $140.1 \mathrm{a}$ & $115.3 \mathrm{a}$ & $13.7 \mathrm{a}$ \\
\hline (Alnus glutinosa) & Control & 314.2 & $127.8 \mathrm{a}$ & $11.6 \mathrm{~b}$ & $0.0 \mathrm{a}$ \\
\hline Yellow poplar & Treated & 314.2 & $25.8 \mathrm{a}$ & $0.0 \mathrm{a}$ & $0.0 \mathrm{a}$ \\
\hline (Liriodendron tulipifera) & Control & 314.2 & $68.0 \mathrm{a}$ & $15.6 \mathrm{a}$ & $1.2 \mathrm{a}$ \\
\hline White ash & Treated & 314.2 & $20.7 \mathrm{a}$ & $1.0 \mathrm{a}$ & $0.0 \mathrm{a}$ \\
\hline (Fraxinus americana) & Control & 314.2 & $20.2 \mathrm{a}$ & $0.6 \mathrm{a}$ & $0.0 \mathrm{a}$ \\
\hline White pine & Treated & 314.2 & $30.6 \mathrm{a}$ & $12.6 \mathrm{a}$ & $11.2 \mathrm{a}$ \\
\hline (Pinus strobus) & Control & 314.2 & $25.5 \mathrm{a}$ & $0.0 \mathrm{a}$ & $0.0 \mathrm{a}$ \\
\hline
\end{tabular}

*Pair values followed by the same lowercase letter are not significantly different at the $P \leq 0.05$ level (Tukey's Studentized Range Test).

fully close bark wounds in the third year after treatment, leaving an exposed area of $7.4 \mathrm{~mm}^{2}\left(0.1 \mathrm{in}^{2}\right)$. PBZ-treated European black alder in the second year after treatment had less wound closure than untreated trees (Table 1).

Yellow poplar, white ash, and white pine were similar in that the rate of closure of bark wounds was not significantly different between untreated trees and those treated with PBZ (Table 1).

High dosage rates of 15.4 or $30.7 \mathrm{~g}(0.5$ or $1 \mathrm{oz})$ PBZ (Experiment II) applied to yellow poplar and American sycamore did not slow the closure of bark wound in the first growing season after wounding (Table 2) at the $P \leq 0.05$ level of confidence.

\section{Wood Discoloration and Decay}

The cross and longitudinal sections cut through the region of bark wounds 3 years after PBZ treatment showed no difference in discoloration between treated and untreated trees for the eight species investigated in Experiment I. Discoloration of the wood immediately around the bark wounds was evident in all eight species, but the discoloration did not extend into wood for more than a few millimeters from the wound area. As examples, wood discoloration in cross sections of control and PBZ-treated red oak are shown in Figure 2. Discoloration in longitudinal sections of white ash associated with bark wounds and PBZ treatment are shown in Figure 3. No visible wood decay due to wounding the bark was observed in either treated or untreated trees.

\section{Closure of Pruning Wounds}

In the first, second, and third growing seasons after treatment, pruning wound closure was significantly inhibited by PBZ in white oak, red oak, and sweetgum. Reduction in the rate of wound closure became evident for European black
Table 2. Area $\left(\mathrm{mm}^{2}\right)$ of 1-year-old bark wounds in yellow poplar (Liriodendron tulipifera) and American sycamore (Platanus occidentalis) trees treated and untreated with $9.6 \mathrm{~g}(0.34 \mathrm{oz}) \mathrm{PBZ}$ by soil drench.

\begin{tabular}{llll}
\hline Species & Treatment & Initial area & 1 year later \\
\hline Yellow poplar & Treated with 15.4 g PBZ & 314.2 & $10.0 \mathrm{a}^{*}$ \\
& Treated with 30.7 g PBZ & 314.2 & $9.1 \mathrm{a}$ \\
& Control & 314.2 & $7.9 \mathrm{a}$ \\
& & & \\
American sycamore & Treated with 15.4 g PBZ & 314.2 & $33.7 \mathrm{a}$ \\
& Treated with 30.7 g PBZ & 314.2 & $21.9 \mathrm{a}$ \\
& Control & 314.2 & $16.5 \mathrm{a}$ \\
\hline
\end{tabular}

*Values followed by the same lower case letter are not significantly different at the $P \leq 0.05$ level (Tukey's Studentized Range Test). 


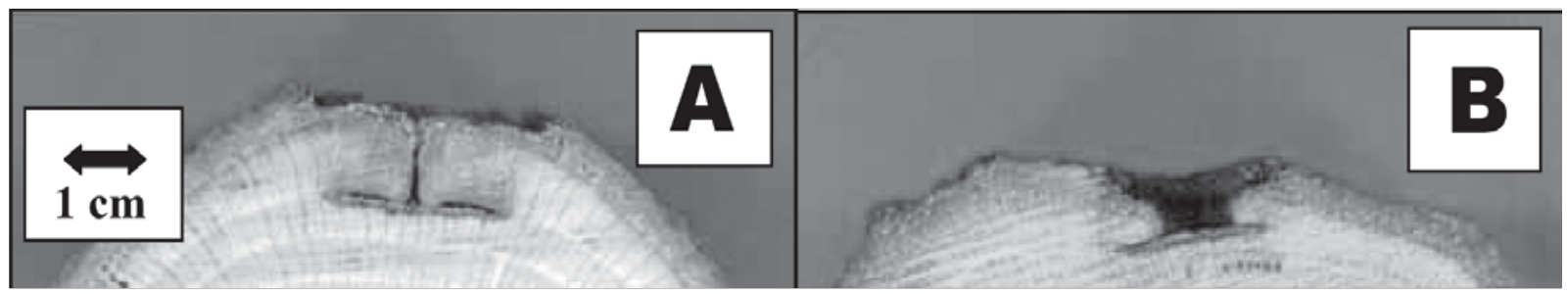

Figure 2. Discoloration and reaction zone compartments as seen in cross sections formed in response to bark wounds in untreated (A) and treated (B) red oak (Quercus rubra) 3 years after treatment with $9.6 \mathrm{~g}$ (0.34 oz) paclobutrazol.

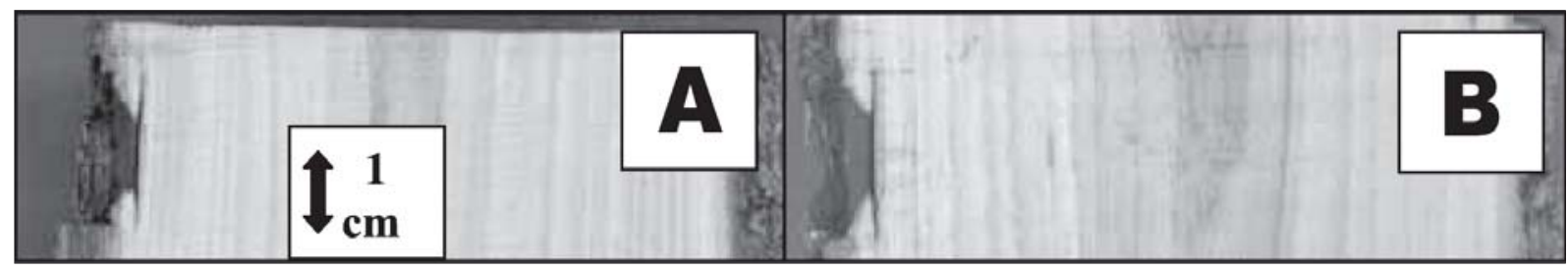

Figure 3. Discoloration and reaction zone compartments as seen in longitudinal sections formed in response to bark wounds in untreated (A) and treated (B) white ash (Fraxinus americana) 3 years after treatment with $9.6 \mathrm{~g}(0.34 \mathrm{oz})$ paclobutrazol.

Table 3. Percentage change in size of pruning wounds of eight tree species treated and untreated with $9.6 \mathrm{~g}$ (0.34 oz) PBZ by soil drench.

\begin{tabular}{|c|c|c|c|c|}
\hline Species & Treatment & $\%$ change in 1 year & $\%$ change in 2 years & $\%$ change in 3 years \\
\hline White oak & Treated & $8.4 b^{*}$ & $7.1 \mathrm{~b}$ & $12.0 \mathrm{~b}$ \\
\hline (Quercus alba) & Control & $23.7 \mathrm{a}$ & $45.0 \mathrm{a}$ & $58.3 \mathrm{a}$ \\
\hline Red oak & Treated & $4.9 \mathrm{~b}$ & $9.8 \mathrm{~b}$ & $16.5 \mathrm{~b}$ \\
\hline (Q. rubra) & Control & $13.0 \mathrm{a}$ & $34.4 a$ & $64.9 \mathrm{a}$ \\
\hline Sweetgum & Treated & $19.5 \mathrm{~b}$ & $19.0 \mathrm{~b}$ & $18.2 \mathrm{~b}$ \\
\hline (Liquidambar styraciflua) & Control & $31.4 \mathrm{a}$ & $68.3 \mathrm{a}$ & $95.5 \mathrm{a}$ \\
\hline Black walnut & Treated & $4.9 \mathrm{a}$ & $3.0 \mathrm{a}$ & $7.6 \mathrm{~b}$ \\
\hline (Juglans nigra) & Control & $5.0 \mathrm{a}$ & $5.3 \mathrm{a}$ & $24.6 \mathrm{a}$ \\
\hline European black alder & Treated & $8.6 \mathrm{a}$ & $20.3 \mathrm{~b}$ & $52.7 \mathrm{~b}$ \\
\hline (Alnus glutinosa) & Control & $10.5 \mathrm{a}$ & $44.3 \mathrm{a}$ & $99.7 \mathrm{a}$ \\
\hline Yellow poplar & Treated & $21.1 \mathrm{a}$ & $50.2 \mathrm{a}$ & $80.3 \mathrm{a}$ \\
\hline (Liriodendron tulipifera) & Control & $22.2 \mathrm{a}$ & $55.3 \mathrm{a}$ & $87.0 \mathrm{a}$ \\
\hline White ash & Treated & $14.3 \mathrm{a}$ & $35.8 \mathrm{a}$ & $55.2 \mathrm{a}$ \\
\hline (Fraxinus americana) & Control & $17.3 \mathrm{a}$ & $41.7 \mathrm{a}$ & $60.2 \mathrm{a}$ \\
\hline White pine & Treated & $36.2 \mathrm{a}$ & $61.3 \mathrm{a}$ & 89.9 a \\
\hline (Pinus strobus) & Control & $24.6 \mathrm{a}$ & $53.6 \mathrm{a}$ & $80.0 \mathrm{a}$ \\
\hline
\end{tabular}

*Pair values followed by the same lower case letter are not significantly different at the $P \leq 0.05$ level (Tukey's Studentized Range Test).

alder in the second and the third growing seasons, and for black walnut in the third growing season after PBZ treatment. In contrast, closure of pruning wounds of yellow poplar, white ash, and white pine was not affected by PBZ treatment (Table 3). 


\section{DISCUSSION}

Although the influence of PBZ treatment on the rate of wound closure varied among the species investigated, PBZ treatment reduced the rate of closure of both bark and pruning wounds in five of the nine species investigated. The exceptions were American sycamore, white ash, white pine, and yellow poplar, in which wound closure was not affected by PBZ treatment. Even excessive dose rates of PBZ applied to American sycamore and yellow poplar did not influence the rate of wound closure (Table 2).

We are not aware of published data showing different responses of shoot growth when soil drench or soil injection application methods are compared. Hence, the data for yellow poplar at different dose rates using both soil injection and soil drench treatment methods were considered comparable. Like yellow poplar, American sycamore is noted for its low sensitivity to growth retardants in terms of shoot growth suppression (Sperry and Chaney 1999) and that low sensitivity appears to exist with regard to growth of callus tissue around wounds in these trees treated with PBZ.

Discoloration of the wood beneath bark wounds was minimal (Figures 2 and 3) and was not influenced by treatment with PBZ. It is known that the amount and intensity of discolored wood that develops after wounding is dependent on the size and depth of the wound within the xylem. Drill wounds that bore into the xylem have appreciably more discoloration than surface wounds (Blanchette 1992). The bark wounds in this study were made in April when the cambium was active and the bark and phloem tissue removed with the cork borer separated easily from the succulent cambial cells with little or no damage to the xylem. Armstrong et al. (1981) also found that wood discoloration associated with bark wounds on black walnut was less when made in the spring rather than in the fall.

The differences among species in the rate of wound closure in response to PBZ treatment found in this study are consistent with species sensitivities to PBZ reflected in the dose rate charts provided by distributors of commercial formulations of PBZ that recommend six rate categories, A through F (1.25 to $4 \mathrm{~g}$ PBZ [0.04 to $0.14 \mathrm{oz}$ ] per inch dbh). White ash, white pine, yellow poplar, and American sycamore are recognized as the least sensitive and are in category $\mathrm{F}$ for the highest dose rate. Sweetgum is quite sensitive to PBZ and is in category B. Both red and white oak are intermediate and are in category $\mathrm{D}$. The dose rate applied to all trees in this study was that for category D or F, depending on the diameter of the tree treated.

PBZ inhibits the biosynthesis of gibberellins produced via the terpenoid pathway (Rademacher 2000). The most frequently reported and best-known consequence of gibberellin synthesis inhibition is reduced cell elongation and shortened shoot internodes. However, growth retardants also are known to suppress cell division both in intact plants and cell suspension cultures (Grossmann 1990). Diameter growth, resulting from cambial activity including cell division, enlargement, and differentiation, is regulated by gibberellins and other plant hormones (Kozlowksi 1971) and has been shown to be reduced in trees by PBZ treatment (Bai et al. 2004). Besides gibberellins, phytosterols are synthesized via the terpenoid pathway, and their production is also inhibited by PBZ (Rademacher 2000; Chaney 2003). Because sterols are structural components of membranes, inhibition of their synthesis accounts for the fungistatic properties of PBZ as well as reduction in cell division (Grossmann 1990) and, possibly, the reduced growth of callus tissue around wounds of some tree species as shown in this study.

Although the results of this study are the first to our knowledge to show an effect of PBZ on wound sealing in trees, PBZ and similar growth retardants have been shown to reduce growth of callus tissue of nonwoody species such as tobacco (Nicotiana spp., Wisconsin 38-W38TO) (Premachandra et al. 1996), rice (Orysa sativa) (Grossmann 1988), and celery (Apium graveolens) (Haughan et al. 1988) on agar media and in cell solution cultures.

Reduction of the rate of closure of both bark and pruning wounds by PBZ in some species persisted at least 3 years, consistent with previous reports for the duration of shoot growth reduction (Chaney 2003). It is known that trees of different species and even different genotypes within a species respond differently to wounding (Shigo et al. 1977; Garrett et al. 1979; Armstrong et al. 1981). The data presented here also show that tree species have different wound responses following PBZ treatment. Indeed, the pattern of PBZ effect on wound closure among species was exactly the same as the varied range of PBZ effects on cambial growth in the same species in another study (Bai et al. 2004).

PBZ applied to the soil is slowly dissolved in water and moves principally upward in the xylem tissue. It tends to bind reversibly to soil and/or to wood as it passes into the xylem and up the vascular system of trees. Sometimes, there is a delay between the time of soil treatment with PBZ and the evidence of growth suppression in a tree crown. The length of this delay is determined by a combined effect of root distribution, transpiration rate, transport drag imposed by adsorption of chemical to the walls of the vascular cells, propensity for chemical in the transpiration stream to be diverted into leaves, and the need to consume existing available endogenous gibberellins before PBZ-induced symptoms become apparent (Lever 1986). PBZ applied in spring can move into trees and affect the biosynthesis and amount of active gibberellins in that growing season, slowing the closure of bark wound and pruning wounds in the year of treatment for some species. However, for other species, the inhibiting effect was not observed in the year of 
treatment or was more pronounced in the second year after treatment. The same variable pattern among species for shoot growth suppression to occur in the year of treatment or to be delayed until the second year after treatment is well documented (Chaney et al. 1996).

Reduction in the rate of closure of both bark and pruning wounds by PBZ could be considered a negative side-effect of PBZ that would expose treated trees to decay organisms and insects for a longer period of time. However, wound surfaces in both PBZ-treated and untreated trees were exposed for at least a portion of the growing season and even for two to three growing seasons in some species. It has been found in peach trees that when an infection court is created for a wound pathogen, disease is most severe when the inoculum arrives at the infection court immediately. If the inoculum arrives later, disease frequency and severity decline with time until the wounded tissues express resistance comparable to that of noninfected bark (Biggs 1986, 1989). There is no indication that wound closure is directly correlated with the amount of discoloration and decay in the wood beneath wounds (Blanchette 1992).

The growth of callus over a bark or pruning wound and the eventual restoration of the vascular cambium that is contiguous with that of the rest of the tree is only one of the steps in wound sealing. In the CODIT model proposed by Shigo (1989), growth of callus over the surface of wounds forms Wall 4, the final step in the wound sealing process. Injury to tree tissues immediately evokes a complex array of physiological and biochemical responses in cells adjacent to the wound (Blanchette 1992). These are separated into rapid responses, such as the release of volatile inhibitors, and slow responses, such as biosynthesis reactions and formation of structural barriers. The rapid responses occur within seconds or minutes after wounding, whereas the slow responses occur over a period of one to many hours. The formation of tissue impermeable to water and penetration by most microorganisms is the most common feature observed in the wound response (Bostock and Stermer 1989). This process of cicatrization, or scar formation (Esau 1977), involves the infusion of lignins, suberin, waxes, and/ or wound gums in the layers of cells immediately subtending the wound surface to form barrier or protective zones in the wood beneath the wound. Hence, slower callus growth over wound surfaces in PBZ-treated trees (Wall 4 formation) does not necessarily mean that PBZ-treated trees will be more susceptible to decay organisms than untreated trees. In fact, visual observation of cross and longitudinal sections through bark wounds of control and PBZ-treated trees revealed no differences in wood discoloration or decay in the eight tree species investigated in this study.

The fungistatic property of PBZ (Chaney et al. 1996) also may enhance the decay resistance of a treated tree over that of an untreated tree. PBZ-treated trees also should require less frequent pruning and fewer pruning cuts due to shoot growth reduction than untreated trees. Hence, any negative effects due to increased time of exposure of wounds may be counterbalanced by the positive effects of PBZ treatment.

\section{LITERATURE CITED}

Armstrong, J.E, A.L. Shigo, A.L., D.T. Funk, E.A. McGinnes, Jr., and D.E. Smith. 1981. A macroscopic and microscopic study of compartmentalization and wound closure after mechanical wounding of black walnut trees. Wood Fiber Sci. 13:275-291.

Bai, S., W. Chaney, and Y. Qi. 2004. Response of cambial and shoot growth in trees treated with paclobutrazol. J. Arboric. 30:137-145.

Biggs, A.R. 1986. Phellogen regeneration in injured peach tree bark. Ann. Bot. 57:463-470.

- 1989. Temporal changes in the infection court following wounding of peach bark are associated with cultivar variation in infection by Leucostoma persoonii. Phytopathology 79:627-630.

- 1992. Anatomical and physiological responses of bark tissues to mechanical injury, pp. 13-40. In Blanchette, R.A., and A.R. Biggs (Eds.). Defense Mechanisms of Woody Plants Against Fungi. SpringerVerlag, Berlin, Germany.

Blanchette, R.A. 1992. Anatomical responses of xylem to injury and invasion by fungi, pp. 76-95. In Blanchette, R.A., and A.R. Biggs (Eds.). Defense Mechanisms of Woody Plants Against Fungi. Springer-Verlag, Berlin, Germany.

Bostock, R.M., and B.A. Stermer. 1989. Perspectives on wound healing in resistance to pathogens, pp. 343371. In Cook, R.J., G.A. Zentmyer, and E.B. Cowling (Eds.). Annual Review of Phytopathology, Volume 27. Annual Reviews, Palo Alto, CA.

Chaney, W.R. 2003. Tree growth retardants: Arborists discovering new uses for an old tool. Tree Care Indust. 14(3):54-59.

Chaney, W.R., G.S. Premachandra, and H.A. Holt. 1996. Physiological basis for benefits of tree growth regulators, pp. 8-18. In Proceedings of the Western Plant Growth Regulator Society, Sacramento, CA, 24-25 Jan. 1996.

Esau, K.1977. Anatomy of Seed Plants (2nd ed.). Wiley, New York, NY. 550 pp.

Fletcher, R.A., A. Gilley, N. Sankhla, and T.D. Davis. 2000. Triazoles as plant growth regulators and stress protectants. Hortic. Rev. 24:55138.

Garrett, P.W., W.K. Randall, A.L. Shigo, and W.C. Shortle. 1979. Inheritance of compartmentalization of wounds in sweetgum and eastern cottonwood. U.S. Forest Service Research Paper NE-443. 4 pp.

Grossmann, K. 1988. Plant cell suspensions for screening and studying the mode of action of plant growth retardants, pp. 89-136. In Maramorosch, K., and G. Sato 
(Eds.). Advances Cell Culture Volume 6. Academic Press, San Diego, CA.

1990. Plant growth retardants as tools in physiological research. Physiol. Plant 78:640-648.

Haughan, P.A., J.R. Lenton, and L.J. Goad. 1988. Sterol requirements and paclobutrazol inhibition of a celery cell culture. Phytochemistry 27:2491-2500.

Kozlowski, T.T. 1971. Growth and Development of Trees, Volume II. Academic Press, New York, NY. 514 pp.

Lever, B.G. 1986. 'Cultar'-A technical overview. Acta Hortic. 179:459-466.

Neely, D. 1970. Healing of wounds on trees. J. Am. Soc. Hortic. Sci. 95:536-540.

Premachandra, G.S., C. Nagasaka, W.R. Chaney, and H.A. Holt. 1996. Response of cells, callus, seeds and plants to a range of flurprimidol concentrations varies in zinnia, sunflower, green pepper, and tobacco. Plant Growth Reg. Soc. Am. Q. 24(3):140-151.

Rademacher, W. 2000. Growth retardants: Effects on gibberellin biosynthesis and other metabolic pathways. Ann. Rev. Plant Physiol. Plant Mol. Biol. 51:501-531.

Sperry, C.E., and W.R. Chaney. 1999. Tree growth regulator effect on phototropism - Its implication for utility forestry. J. Arboric. 25: 43-46.

Shigo, A.L. 1984. Compartmentalization: A conceptual framework for understanding how trees grow and defend themselves. Ann. Rev. Phytopathol. 22:189-214.

— 1989. A New Tree Biology (2nd ed.). Shigo and Trees, Associates, Durham, NH. 618 pp.

Shigo, A.L., W.C. Shortle, and P.W. Garrett. 1977. Genetic control suggested in compartmentalization of discolored wood associated with tree wounds. For. Sci. 23:179-182.

Zimmermann, M.H., and C.L. Brown. 1971. Trees: Structure and Function. Springer- Verlag, New York, NY. 336 pp.

\author{
${ }^{1}$ Department of Computer Science \\ Southern University and A\&M College \\ P.O. Box 9221 \\ Baton Rouge, LA 70813, U.S. \\ ${ }^{2 *}$ Department of Forestry and Natural Resources \\ 715 West State Street \\ Purdue University \\ West Lafayette, IN 47907, U.S. \\ chaneyw@purdue.edu
}

\author{
${ }^{3}$ Urban Forestry Program \\ Southern University and A\&M College \\ P.O. Box 11288
}

Baton Rouge, LA 70813, U.S.

"Corresponding author.
Résumé. Des expériences ont été menées pour vérifier les effets du paclobutrazol sur la cicatrisation des blessures faites à l'écorce ou encore lors d'élagage de branches auprès de neuf espèces d'arbres. Le paclobutrazol était appliqué autant par mouillage sur le sol que par injection dans le sol. Des blessures circulaires $(2 \mathrm{~cm}$ de diamètre) ont été faites sur l'écorce des tiges principales et des branches ont été élaguées, et ce à la fois sur des arbres traités et non traités au même moment où l'application de paclobutrazol a été faite au printemps. Le taux de fermeture de la blessure, une fois le traitement fait, a été évalué une, deux et trois saisons de croissance plus tard. Le taux de fermeture des blessures à l'écorce était diminué avec le traitement au paclobhutrazol chez le noyer noir, l'aulne européen, le chêne rouge, le copalme d'Amérique et le chêne blanc. Il n'y avait pas de différence dans le taux de fermeture des blessures sur l'écorce des arbres traités ou non chez le platane occidental, le frêne blanc, le pin blanc et le tulipier de Virginie. Le taux de fermeture des blessures d'élagage était diminué chez le noyer noir, l'aulne européen, le chêne rouge, le copalme d'Amérique et le chêne blanc, mais il n'était pas influencé par le traitement au paclobutrazol chez le frêne blanc, le pin blanc et le tulipier de Virginie. L'effet inhibiteur du paclobutrazol sur le taux de fermeture à la fois des blessures sur l'écorce et des blessures d'élagage a persisté chez certaines espèces au moins trois ans.

Zusammenfassung. Bei 9 Baumarten wurden Experimente durchgeführt, um die Auswirkungen von Paclobutrazol auf den Wundverschluss von Rindenwunden oder Astungswunden zu untersuchen. Paclobutrazol wurde entweder über den Boden oder als Injektion appliziert. Während der Applikation im Frühjahr wurden in die Rinde des Hauptstamms Wunden mit $2 \mathrm{~cm}$ Durchmesser gebohrt und es wurden Äste von behandelten und unbehandelten Bäumen geschnitten. Der Grad des Wundverschlusses wurde in der 1., 2. und 3. Wachstumsperiode nach der Behandlung gemessen. In behandelten Walnüssen, Erlen, Roteichen, Amberbäumen und Weißeichen reduzierte sich der Wundverschluss. In der Rinde von behandelten und unbehandelten Platanen, Eschen, Kiefern und Pappeln gab es keine Unterschiede. Es gab eine reduzierte Wundverschlussrate bei Astwunden an Walnuss, Schwarzerle, Roteiche, Amberbaum und Weißeiche, aber es war nicht beeinflusst durch die Behandlung bei Esche, Kiefer und Pappel. Der hemmende Effet von Paclobutrazol auf Wundverschluss hielt in einigen Arten mindestens 3 Jahre an.

Resumen. Se investigaron los efectos del paclobutrazol sobre el cierre de las heridas hechas a través de la corteza o resultantes de la poda de ramas en nueve especies de árboles. Se aplicó paclobutrazol utilizando los métodos de zanjas o inyección en el suelo. Se hicieron heridas circulares ( $2 \mathrm{~cm}$. de diámetro) en la corteza del tallo principal y las ramas fueron podadas, de árboles tratados y no tratados, en el momento de aplicación del paclobutrazol en primavera. La tasa de cierre de la herida fue determinada una, dos y tres estaciones de crecimiento después del tratamiento. La tasa de cierre de la herida en la corteza fue menor en los árboles tratados de nogal negro, aile europeo, encino rojo, liquidambar y encino blanco. No hubo diferencia en la tasa de cierre de las heridas entre árboles tratados y no tratados de sicomoro americano, fresno blanco, pino blanco o álamo amarillo. La tasa de cierre de la herida de la poda fue reducida en nogal negro, aile europeo, encino rojo, liquidambar y encino blanco, pero no fue influida por el tratamiento de pacloutrazol en fresno blanco, pino blanco o álamo amarillo. El efecto inhibitorio del paclobutrazol sobre el cierre de las heridas tanto de la corteza como de las podas en algunas especies persistió al menos tres años. 